\title{
The Impact of Instruction in English on Learning Anxiety
}

\section{Sachiko Maruoka}

Seikei University

\section{Emiko Matsui \\ Toita Women's College}

\section{Reference Data}

Maruoka, S., \& Matsui, E. (2020). The impact of instruction in English on learning anxiety. In P. Clements, A. Krause, \& R. Gentry (Eds.), Teacher efficacy, learner agency. Tokyo: JALT.

https://doi.org/10.37546/JALTPCP2019-23

In L2 acquisition, there has long been a debate as to whether instructors should conduct classes in English or through the approach of code-switching. This study was conducted to investigate the impact on learning anxiety in classes taught only in English. The survey was conducted with 55 students at a university in central Tokyo. A questionnaire and interviews were carried out to see how the students' learning anxiety changed over a period of four months of instruction. The results showed that the students with prior experience of lessons conducted in English (LCE) had reduced learning anxiety over the period. Qualitative analysis was also conducted regarding the factors in students' learning anxiety. The researchers argue that the results of this research can be used to enhance teacher efficacy through the sharing the effects of lessons conducted in English with instructors teaching English in Japan.

第二言語習得において教員の間では、オールイングリッシュあるいはコードスイッチングのどちらがより効果的に英語の指 導ができるか長い間議論されている。本研究では、オールイングリッシュ指導がもたらす影響を論証する。東京都内の大学に 在籍する大学生 55 名を対象にアンケートと個別面談を実施し、オールイングリッシュクラスを受講する学生の不安度が 4 ヶ 月でゼのように変化したかを分析した。その結果、大学入学前にオールイングリッシュクラスの受講経験を有する学生は、英語 学習に対する不安度を有意に軽減させたことが分かった。また、学生が授業で感じた不安材料とそれに影響を与えた要素を 考察した。その研究結果をもとに、オールイングリッシュ指導の有効性や今後教員間で効果的な指導のために共有できるもの はなにかを提案し論じる。 $\mathrm{n}$ English education in Japan, based on its release of An Action Plan to Cultivate _ "Japanese with English Abilities" in 2003, MEXT (Ministry of Education, Culture, Sports, Science and Technology, 2009) stated that "classes, in principle, should be conducted in English to enhance the opportunities for students to be exposed to English, thereby transforming classes into real communication scenes." Since this statement, schools have been attempting to conduct classes in English according to MEXT's plan. Moreover, MEXT's release of the English Education Reform Plan in 2014 aims to accelerate the number of classes conducted in English by 2020.

In contrast to the situation that the MEXT plan seeks to redress, the institution at which this study was undertaken has been conducting classes in English since the foundation of the university more than 100 years ago. However, some of the faculty worry about students' understanding of English-language instruction and the negative impact of this on their learning anxiety. The purpose of this study was to monitor not only the effects on language acquisition but also on students' learning anxiety in lessons conducted in English (LCE). For this study, the FLCAS (Foreign Language Classroom Anxiety Scale) was used to collect quantitative data. To better discern further factors related to students' learning anxiety in English classes, interviews were also conducted. It was hoped that this would help the instructors to better understand students' learning anxiety in LCE in order to ease students' learning anxiety and to enhance teacher efficacy.

\section{English-Only Instruction and Code Switching}

Debate continues regarding the advantages of English-only instruction and codeswitching in language teaching and learning.

The term "all English," which is a Japanese-English term, is often used for LCE. The understanding of this term in educational institutions and among students in Japan is that all instruction and explanations are conducted in English during class. This idea 
stems from Krashen's input hypothesis (Krashen \& Terrell, 1983), which argues that listening and reading comprehension are of primary importance and that speaking and writing skills naturally emerge as time passes. In other words, the more input the students have prior to output, the more efficiently they can develop their language skills. In an EFL environment, most students do not have enough exposure to L2 outside the classroom. Therefore, in a later discussion of "teacher talk," Krashen (1981) states that teachers should speak authentic English as much as possible to help students acquire the target language. If they do so, students will have more opportunities for exposure to the target language. The research on teacher talk has shown that it comprises around $70 \%$ of classroom language, and that the more input is provided, the more successful language learning will be (Chaudron, 1988; Cook, 2001; Rahayu \& Margana, 2018). There is also a belief that the use of the $\mathrm{L} 2$ maximizes input and leads to effective acquisition of the target language (Cook, 2001; Ford, 2009; Kim \& Elder, 2005; Macaro, 2001; Mishima, 2016; Stephens, 2006; Storch \& Wiggleworth, 2003). Cook (2001) states that the L2 can be successfully acquired if it is separated from $\mathrm{L} 1$ and adds that if the major problem in learning is derived from the L1, we need to eliminate the L1 when learning $\mathrm{L} 2$.

However, as Rahayu and Margana (2018) point out, teachers need to carefully make sure that students are understanding exactly what they need to understand, so there are disadvantages to English-only instruction. To solve this issue, code-switching-based instruction is used for the purpose of satisfying the communicative needs of speakers who have low proficiency in the L2 (Moore, 2002). In code-switching-based instruction, the L1 is used to provide information about the meaning of vocabulary words (Liu et al., 2004; Macaro \& Lee, 2012; Rolin-lanziti \& Brownlie, 2002). It is also argued that use of the L1 and L1 translation cannot be avoided when learning a new language, which offers advantages for both learners and teachers (Rahayu \& Margana, 2018). In addition, Rahayu and Margana (2018) state that although the L2 can be acquired effectively through the teacher's use of code-switching, some students may be affected by the reduction in L2 exposure. Focusing on Japanese learners, Erikawa et al. (2016) contend that the use of the L1 in L2 acquisition is important in order for students to understand conceptual content and think critically.

\section{Research Questions}

This study investigates the impact of instruction in English on students' learning anxiety. In order to better understand students' anxiety, three research questions were formulated:

RQ1. What aspects of class, such as classroom management, activities, interaction, and instruction affect 1st-year university students' anxiety regarding learning English?
RQ2. What aspects of university courses conducted in English affect students anxiety regarding learning English?

RQ3. What coping mechanisms do students use to overcome their anxiety?

\section{Method}

The Research Environment

The study was conducted in a 1st-year English class at a women's university in central Tokyo, where 1st-year English classes have been conducted in English for more than 100 years (since the university was founded in 1916). The classes are divided into 22 levels based on a placement test conducted during the orientation period in April, at the beginning of the first semester. The 1st-year English class is offered twice a week, for a total of 30 sessions over a 15-week semester. The class is a required course for all 1 st-year students and is designed to help students improve all four language skills. A further purpose of the class is to develop the critical thinking skills that are necessary for students in their studies.

\section{Participants}

A total of 55 students participated in this study, aged from 18 to 20 . Twenty-seven students were from a lower-intermediate class, which is the 16th highest out of the 22 levels, and 28 students were from an upper-beginning class, the 16th level. The classes were divided based on the scores on the Comprehensive English Language Test for Learners of English (CELT) by McGraw-Hill. Although this test is not compatible with the TOEIC or EIKEN, most students in the lower-intermediate classes hold Pre-Grade 2 in the EIKEN and those in the upper-beginning classes hold Grade 3. The lowerintermediate class uses the textbook Reading and Vocabulary Development Level 3: Cause \& Effect (Ackert et al., 2014b), and the upper beginning class uses Reading and Vocabulary Development Level 2: Thoughts \& Notions (Ackert et al., 2014a). In these two classes, the students have speaking practice sessions based on Nation and Newton's (2009) 4/3/2 Fluency Activity at the beginning of each class.

\section{Data Collection}

This study used a mixed methodology. To collect quantitative data, we used the Foreign Language Classroom Anxiety Scale (FLCAS), which was originally developed by Horwitz, Horwitz, and Cope (1986) and translated by Yashima et al. (2009; see Appendix). The questionnaire was conducted during the second session of the class in April 2019, and 
in the 28th session in July 2019. The total number of questions in this survey is 30 . The Likert-scale for each item is from 1 (strongly agree) to 5 (strongly disagree). One indicates the least anxiety and five the most. Reverse scoring was applied to eight items, which are indicated with an asterisk. Also, for this study, several questions asking about students' prior experience with LCE were added. These questions asked whether or not they had any experience of $\mathrm{LCE}$, and for those answering yes, at what institution(s), and when and how long the instruction lasted. At the end of the questions, there was a space added for the students to write freely about their learning anxiety, taking LCE, and what they thought about class activities.

As for the qualitative data, interviews were conducted with 19 students. Among the 55 students, there were 19 who left comments regarding LCE on the questionnaire. After we obtained informed consent from the students prior to the study, we interviewed each of them for approximately 10 minutes during class while other students were working on other tasks. The interview was conducted in Japanese by the two authors.

\section{Data Analysis and Results}

\section{Questionnaire}

As noted above, the students answered a questionnaire consisting of 30 Likert-scale items on two occasions: once in April and once in July. The survey was designed so that the larger numbers represented greater anxiety. Descriptive statistics are shown in Table 1. We first checked for normal distribution with kurtosis and skewness, which should be between \pm 2 . We then used a $t$-test with normal distribution to check for statistical significance; otherwise, a Mann-Whitney U test would need to be used. However, questionnaire data from both April and July showed normal distributions.

Table 1. Descriptive Statistics of Survey Results

\begin{tabular}{lccccccc}
\hline & number & $M$ & \multicolumn{1}{c}{$S D$} & Max & Min & Kurtosis & Skewness \\
\hline April & 55 & 3.831 & 0.487 & 4.758 & 2.242 & 0.790 & -0.505 \\
July & 47 & 3.451 & .538 & 4.909 & 2.182 & 0.438 & 0.327 \\
\hline
\end{tabular}

We performed a cross-comparison $(I=5)$ to check for statistical significance, which has a risk of a Type I error, so we applied Bonferroni's adjustment $(p<0.05 / \mathrm{N})$. This means that with five times of multiple-comparison, a $p$ value less than 0.01 was considered statistically significant.
When the questionnaire data collected from the two classes in April was compared to that of July, a statistical difference was found in both cases (Table 2). The results indicate that the students' responses in both classes regarding learning anxiety were significantly lower in July.

Table 2. Statistical Significance From April to July in Each Class

\begin{tabular}{ccc}
\hline & $\begin{array}{c}\text { The upper beginner class } \\
(n=28)\end{array}$ & $\begin{array}{c}\text { the lower intermediate class } \\
(n=27)\end{array}$ \\
\hline$p(\mathrm{~T}<=t)$ (two-tail) & $0.006^{*}$ & $0.010^{*}$ \\
\hline
\end{tabular}

Note. ${ }^{*} p<0.01$.

In order to analyze the data more deeply, we divided the students into two groups: a group of 25 students without LCE experience, and a group of 30 students with it, regardless of the type of institution, age and length of experience. It should be noted that in this study prior experience did not mean early exposure to English.

We compared the data for each group to see (a) the difference after four months from April to July in each group, and (b) the difference between the two groups in April and July. In the comparison of April and July for each group, the group with prior experience showed a significant difference, which means they had less anxiety in July. On the other hand. the group without prior experience did not show a significant difference (see Table 3). These results indicate that only the group with prior experience statistically lowered their learning anxiety from April to July.

Table 3. Statistical Significance from April to July in Each Group With and Without Prior Experience of LCE

\begin{tabular}{llccc}
\hline Group & & April & July & $p(\mathrm{~T}<=t)$ (two-tail) \\
\hline With & $M$ & 3.793 & 3.348 & $0.001^{*}$ \\
experience & $S D$ & 0.509 & 0.499 & \\
& & & & \\
W/o & $M$ & 3.879 & 3.718 & 0.218 \\
experience & $S D$ & 0.466 & 0.565 & \\
\hline
\end{tabular}

Note. $* p<0.01$. 
Comparison of the two groups in April and in July revealed that although there was no difference in April, there was a significant difference in July, indicating less anxiety in the group with prior LCE experience after 4 months (see Table 4). This also means that although both groups' learning anxiety in April was not statistically different, the anxiety of the group with prior LCE experience was statistically lower than that of the group without it in July.

Table 4. Statistical Significance in Groups With and Without Prior LCE Experience in April and July

\begin{tabular}{|c|c|c|c|c|c|}
\hline \multirow[t]{2}{*}{ Month } & \multicolumn{2}{|c|}{ With experience } & \multicolumn{2}{|c|}{ w/o experience } & \multirow{2}{*}{$\begin{array}{l}p(\mathrm{~T}<=t) \\
\text { (two-tail) }\end{array}$} \\
\hline & $M$ & $S D$ & $M$ & $S D$ & \\
\hline April & 3.793 & 0.509 & 3.879 & 0.466 & 0.521 \\
\hline July & 3.348 & 0.499 & 3.718 & 0.565 & $0.001 *$ \\
\hline
\end{tabular}

Note. $* p<0.01$.

\section{Students' Comments in the Interview}

As stated earlier, we interviewed 19 students who wrote comments on the questionnaire related to learning anxiety. The students' comments during the interview on how they felt about LCE included what they thought had worked to ease their learning anxiety. These included: 1) a friendly and supportive atmosphere in class, 2) getting accustomed to LCE in college, 3 ) the gap between skill-focused instruction in college and accuracyfocused instruction in high school, and 4) communication in English. Examples of the students' comments for each of these categories are included below. They have been translated into English by the authors.

A friendly and supportive atmosphere: Although I don't have confidence in my understanding of the teacher's instruction, the relaxing atmosphere helps me to not worry about making mistakes.

I barely understand instruction in English, but I can ask my classmates.

Getting accustomed to the LCE: Though I didn't understand (instruction in English) at the beginning of the year, I got used to it.

I feel anxious when I imagine the situation in which I don't understand the instructions, but l'm ok now.
The gap between college and high school: While my prior experience of LCE when I was a kid was just about activities like games, it's interesting for me to take academic LCE at college, unlike junior and senior high school.

I enjoy the speaking activities and group-work, which we didn't have in high school

I feel uncomfortable with the gap between the teaching/learning styles of college and that of high school.

I feel anxious about the fact that we don't always have a clear answer.

Communication in English: As I have no prior experience of taking LCiE, I feel nervous when the instructor asks me a question and I have to answer immediately.

I have prior experience, but I feel nervous when I don't understand the instruction.

We also noted how differently three of the students without prior experience responded to LCE. Student A said, "I was nervous at the beginning but became used to English instruction as time passed." Her instructor observed that she followed the instructor's advice on studying in college and did her best outside of class. Student B said, "I'm not so interested in improving my English because I did not understand English grammar in junior and senior high school, but now I realize I need it for my future." Although she had no intrinsic motivation for developing her English, she was aware of the necessity of English proficiency for the future, especially for finding a job. She also said, "It was not very easy for me to ask for help from others in the group at the beginning, but now I don't mind it since I get along with them." Student $\mathrm{C}$ expressed her anxiety stemming from having no confidence in her English ability, as well as her hesitation over asking questions of her classmates, which came from her assumption that the other students had superior English skills. She said, "all the other group members know everything in the textbook," and "If I ask a question, it will be a bother for them." However, according to her instructor's observation, most of her homework, which mainly involved preparing for the next class, was incomplete, while most of the other students at least finished theirs. This prevented her from participating in activities and interactions with the others and may have made them less enjoyable, resulting in a gap between her and the others regarding her nervousness about classes. She also stated that she felt more comfortable in lecture-style classes rather than communicative ones, which she had not had in high school. 


\section{Discussion}

The results of quantitative analysis showed that anxiety over learning English in LCE decreased among the students as a whole during the first 4 months of the course. However, when we assess the students separately on whether they had prior experience of taking LCE, only the students with prior experience showed significantly less anxiety during that time. This suggests that the students' prior experience of taking LCE is one of the key factors in easing their anxiety. Accordingly, to help university students in Japan reduce anxiety regarding LCE, activities that develop students' cognitive and communicative skills should be implemented in addition to English instruction at the earlier stages of English education, even if it is done so gradually, instead of putting too much emphasis on accuracy and vocabulary acquisition. At the same time, this shift will make it possible to realize the aims of MEXT's Course of Study. Nonetheless, junior and senior high schools seem to face strong washback effects from entrance exams, which have recently been a controversial issue in Japan's English education system. As a result, the processes and direction of educational reform should be carried out with great care and consideration for students' cognitive and psychological development.

From the comments the students made during the interview, we were able to assess their attitudes towards LCE. These comments indicated that becoming accustomed to LCE at college, a helpful and supportive atmosphere, and communicative activities were key factors in lowering anxiety. In particular, interviews indicated that the gap between college and high school can have both positive and negative effects on anxiety. Although the students were supposed to develop more interactive communication skills in English at the university level, they had become accustomed to seeking and receiving one specific answer through activities in high school that were focused on accuracy, and that made them afraid to make mistakes. For some of the students, the gap between high school and university has actually helped them overcome the fear of making mistakes, but some found it difficult to do so and to practice communicating by trial and error, which is one of important factors in improving communication skills. For those students, it seems that accuracy was the only criterion that they had to evaluate their own development. Again, this is in part due to the washback effect of entrance exams. As stated above, in order to reduce university students' anxiety, it is necessary to implement MEXT's Action Plan, which emphasizes a shift towards developing students' higher cognitive and interactive skills, and in order to achieve this, educational reforms including those related to entrance exams should be carefully and resolutely implemented if they are to be beneficial for students.
Interviews also revealed changes in the students' mindsets from the beginning of university instruction, where they felt at a disadvantage in an academic LCE that employed skill-focused communicative activities that were different from the ones they had experienced in high school and which took place in a completely new environment with new classmates, to 4 months later, when they had become more used to LCE and had developed relationships with their peers, which in turn helped create a helpful and supportive atmosphere in which they felt secure and were less hesitant about making mistakes and asking questions when they did not understand the lecturer's English instructions. At the same time, some of the students displayed differing attitudes toward overcoming the difficulties they found in LCE. These differences may depend on variables such as self-study skills, self-confidence based on prior experiences learning English, and personality.

\section{Conclusion}

In this study, we investigated how students' anxiety regarding learning English changed during LCE. We found that prior experience of LCE was key in reducing students' anxiety. Furthermore, the results indicated that the gap between the skill-focused teaching styles of college and the accuracy-focused classes in high school had both positive and negative effects on the students' anxiety. For the students who still felt comfortable when there was a single correct answer to each question, there seemed to be a strong washback effect of Japanese university entrance exams. It can be said that the opportunity to experience LCE should be provided for students prior to university and gradually increased, which would more closely match the aims of MEXT, such as providing opportunities for real communication, implementing high-level linguistic activities including presentations, debates, and negotiations, and developing students' output proficiency $(2003 ; 2009 ; 2014)$. Moreover, despite there being several issues regarding implementation (such as the $\mathrm{L} 2$ abilities of the teachers), the system of articulation between high school and university, as well as university entrance exams for English, need to be thoroughly reconsidered. At the same time, university instructors need to be aware of the L2 instructional gap between high school and university and plan and adjust lesson content by carefully monitoring differences in students' educational backgrounds, previous exposure to English-language instruction, and motivation.

Given the finding that a comfortable atmosphere and peer support, as well as good habits of self-study, aided students in overcoming anxiety related to LCE, the main pedagogical implication for university teachers is that they should introduce more group work, especially at the beginning of a school year, and encourage students to support 
each other during activities so that they can develop a rapport that will provide them with a secure learning atmosphere and allow them to focus on skill development.

Although this research revealed several factors that can lower students' anxiety, more research is necessary to further consider which specific aspects of instruction and learning can reduce the anxiety of students experiencing LCE for the first time at college, how long it takes for this type of anxiety to decline significantly, and how soon university students should be exposed to instruction in English. In addition, as stated earlier, one of the limitations of the study is the difficulty of separating students' responses regarding anxiety about learning English from their nervousness over taking a new course with new classmates in a new environment. As such, further research is required to consider appropriate methods of investigating the students' anxiety and appropriate responses to that anxiety.

Despite the need for further research, we believe that this study illustrates the potential of conducting classes in English at university. In order to meet Japanese learners' needs and foster better comprehension, university instructors must closely monitor students and understand that the reduction of anxiety in the classroom environment is crucial to improving $\mathrm{L} 2$ acquisition.

\section{Acknowledgments}

We would like to express our gratitude to Yukiko Yamada, Junko Sugimoto, and Bernard Wilson at the University of Sacred Heart and our students for allowing the authors to analyze and publish the data in this study.

\section{Bio Data}

Sachiko Maruoka is currently an English lecturer at university and also works with several companies and publishers developing self-study materials. She holds an MA in TESOL from Teachers College, Columbia University. Her research interests include learner autonomy, self-regulated learning, and cooperative learning. <sachikomaruoka@ gmail.com>

Emiko Matsui is an associate professor at Toita Women's College. She holds an MA in TESOL from Teachers College, Columbia University. Her research interests include English language education, pragmatics, and early childhood education. <emi1214ato@ gmail.com>

\section{References}

Ackert, P., Lee, L., Hawkins, E., Haynes, H., Beck, J., \& Kostarelis, S. (2014a). Reading and vocabulary development level 2: Thoughts \& notions (Updated Edition). Boston, MA: Cengage Learning.

Ackert, P., Lee, L., Hawkins, E., Haynes, H., Beck, J., \& Kostarelis, S. (2014b). Reading and vocabulary development level 3: Cause \& effect (Updated Edition). Boston, MA: Cengage Learning.

Chaudron, C. (1988). Second Language classrooms: Research on teaching and learning. Cambridge, UK: Cambridge University Press.

Cook, V. (2001) Using the first language in the classroom, Canadian Modern Language Review, 57 (3), 402-423. https://doi.org/10.3138/cmlr.57.3.402

Erikawa, H., Hagiwara, l., Yoshioka, J., \& Ikeda, M. (2016). オールイングリッシュvs コード・スイッチング [English-only instruction vs Codeswitching]. The New English Classroom, 3, 7-9.

Ford, K. (2009) Principles and practices of L1/L2 use in the Japanese university EFL classroom. JALT Journal, 31(1), 63-80.

Horwitz, E. K., Horwitz, M. B., \& Cope, J. (1986). Foreign language classroom anxiety, The Modern Language Journal, 70(2), 125-132. https://doi.org/10.2307\%2F327317

Kim, S., \& Elder, C. (2005). Language choices and pedagogic functions in the foreign language classroom: A cross-linguistic functional analysis of teacher talk. Language Teaching Research, 9(4), 355-380. https://doi.org/10.1191\%2F1362168805lr173oa

Krashen, S. D. (1981). Second language acquisition and second language. Oxford, UK: Pergamon Press. Retrieved from http://www.sdkrashen.com/content/books/sl_acquisition_and_learning. pdf\#search=\%27Second+language+acquisition+and+second+language $\% 27$

Krashen, S. D., \& Terrell, T. D. (1983). The natural approach. Prentice Hall International.

Liu, D., Ahn, G., Baek, K., \& Han, N. (2004). South Korean high school English teachers' code switching: Questions and challenges in the drive for maximal use of English in teaching. TESOL Quarterly, 38(2), 605-638. https://doi.org/10.2307/3588382

Macaro, E. (2001). Analysing student teachers' codeswitching in foreign language classroom: Theories and decision making. The Modern Language Journal, 85(4), 531-548. https://doi. org/10.1111/0026-7902.00124

Macaro, E., \& Lee, J. H. (2012). Teacher language background, codeswitching, and English-only instruction: Does age make a difference to learners' attitudes? TESOL Quarterly, 47(4), 717-742. https://doi.org/10.1002/tesq.74

MEXT. (2003). An action plan to cultivate "Japanese with English abilities." Retrieved from http:// www.mext.go.jp/english/b_menu/shingi/chukyo/chukyo3/015/siryo/04042301/001. htm 
MEXT. (2009). The course of study for senior high schools guidelines explanation: Foreign languages (English). Retrieved from http://www.mext.go.jp/component/a_menu/education/micro_detail/_ icsFiles/afieldfile/2010/01/29/1282000_9.pdf

MEXT. (2014). The English education reform plan corresponding to globalization. Retrieved from http://www.mext.go.jp/en/news/topics/detail/__icsFiles/afieldfile/2014/01/23/1343591_1.pdf

Mishima, M. (2016). Searching for the best medium of instruction: Japanese university students' views on English-only instruction in EAP courses, The Journal of Rikkyo University Language Center, 36, 15-27. https:// doi.org/10.14992/00012587

Moore, D. (2002). Case study: Code-switching and learning in the classroom. International Journal of bilingual Education and bilingualism, 5(5), 279-293. https://doi. org/10.1080/13670050208667762

Nation, P., \& Newton, J. (2009). Teaching ESL/EFL listening and speaking. New York, NY: Routledge. Rahayu, D. I., \& Margana (2018). Comparing the effects of L2-based with code-switching-based instruction on EFL speaking classes, Journal of Language Teaching and Research, 9(5), 946-952. https://doi.org/10.17507/jltr.0905.07

Rolin-lanziti, J., \& Brownlie, S. (2002). Teacher use of the learners' native language in the foreign language classroom. Canadian Modern Language Review, 58(3), 402-426. https://doi.org/10.3138/ cmlr.58.3.402

Stephens, M. (2006). The use and abuse of Japanese in the university English class. The Language Teacher, 30(8), 13-18.

Storch, N., \& Wigglesworth, G. (2003). Is there a role for the use of the L1 in an L2 setting? TESOL Quarterly, 37(4),760-770. https://doi.org/10.2307/3588224

Yashima, T., Noels, K., Shizuka, T., Takeuchi, O., Yamane, S., \& Yoshikawa, K. (2009). The interplay of classroom anxiety, intrinsic motivation, and gender in the Japanese EFL context. Journal of Foreign Language Education and Research, 17, 41-64.

\section{Appendix}

Student Questionnaire

一年英語 アンケート

年月日

ご自身について教えてください。記入した内容は本研究の目的のみに用い、個人が特定されること のない形で発表することをお約束します。

\section{とてもあてはまる} 全くあてはまらない

$\begin{array}{lllll}5 & 4 & 3 & 2 & 1\end{array}$

1. 外国語の授業で話すとき自信がもてない。

2. 外国語の授業で間違うことは気にならない。*

3. 外国語の授業で当てられると思うと体が震える。

4. 外国語の授業で先生の言つていることが理解できないととても不安だ。

5. もつと外国語の授業があってもよいと思っている。*

6. 外国語の授業中に、授業と関係ないことを考えていることがよくある。

7. 他の生徒の方が自分よりよくできると思う。

8. 外国語の授業中に行われるテストではだいたい落ち着いている。*

9. 外国語の授業で準備なしに話さないといけない時、パニックになる。

10. 外国語の単位を落としたときの影響が心配だ。

11. 外国語の授業で動摇する人の気持ちがわからない。*

12. 外国語の授業では、緊張のあまり知っていたことも忘れてしまうときがある。

13. 外国語の授業で自分からすすんで答えるのは恥ずかしい。

14. 外国語をネーティブスピーカーと話すとき緊張しない。*

15. 先生が何を訂正しているのか理解できないとき動摇する。

16. 外国語の授業の予習を十分にしていても心配になる。

17.よく外国語の授業を休みたくなる。

18. 外国語の授業で話すのに自信がある。*

19. 先生が自分の間違いをいちいち直しそうなので心配だ。

20. 外国語のクラスで当たりそうになると胸がどきどきする。 
21. 外国語のテスト勉強をすればするほど、混乱する。

22. 外国語の授業の予習をしなければならないというプレッシャーを感じない。*

23. 常に他の学生の方が外国語で話すのが上手だと感じている。

24. 他の学生の前で外国語を話すとき自意識がとても高くなる。

25. 外国語のクラスは進むのが速いのでついていけるかどうか心配である。

26. 他の科目よりも外国語のクラスの方か緊張する。

27. 外国語のクラスで話すとき緊張したり混乱したりする。

28. 外国語の授業の前には、自信をもちリラックスしている。

29. 先生の言うことがすべて理解できないと不安になる。

30. 外国語を話すために勉強しないといけない文法規則の数に圧倒される。

31. 私が外国語を話すと他の学生が笑うのではないかと思う。

32. ネーティブスピーカーに会うときおそらくリラックスしていられると思う。*

33. 先生が、前もって準備していなかった質問をすると緊張する。

1. これまでにオールイングリッシュの授業(先生が原則英語だけを話して進める授業)を受けた ことがありますか?

はい/いいえ

2. で「はい」答えた人のみ次の質問に答えてください。

1）小学校の授業でオールイングリッシュの授業を受けたことがありますか? はい/いいえ

それは何年生の時ですか?

1 年・ 2 年・ 3 年・ 4 年・ 5 年・ 6 年(複数回答可)

期間間 頻度週に回

2） 中学校の授業でオールイングリッシュの授業を受けたことがありますか? はい/いいえ

それは何年生の時ですか?

1 年・ 2 年・ 3 年 $($ 複数回答可)

期間間 頻度週に
3）高校の授業でオールイングリッシュの授業を受けたことがあますか?

はい/いいえ

それは何年生の時ですか?

1 年・ 2 年・ 3 年 (複数回答可)

期間間 頻度週に回

4) その他の機関(英会話スクールなど)でオールイングリッシュの授業を受けたことがあますか? はい/いいえ

それは何年生の時ですか?

$\begin{array}{llll}\text { から } & \text { まで } & \text { 年間 } \\ \text { 頻度 } & \text { 週 } & \text { に } & \text { 回 }\end{array}$

3. 今まで海外で生活した経験はありますか?

はい/いいえ

1）それは何歳の時ですか?

( ) 歳から ( ) 歳まで $(）$ 年間

2) 滞在した国はごこですか?

( )

3）使用言語は何でしたか? （

（学校など場所によって言語が違った場合は以下記入してください）

家の中( )

学校 ( )

地域 $($ ) 